Full length Article

\title{
Potential use of ricotta cheese whey for the production of lactobionic acid by Pseudomonas taetrolens strains
}

\author{
Stefania De Giorgi ${ }^{\mathrm{a}, \mathrm{b}}$, Noura Raddadi ${ }^{\mathrm{a}, *}$, Angelo Fabbri ${ }^{\mathrm{b}}$, Tullia Gallina Toschi ${ }^{\mathrm{b}}$, Fabio Fava $^{\mathrm{a}}$ \\ a Department of Civil, Chemical, Environmental and Materials Engineering (DICAM), University of Bologna, Italy \\ ${ }^{\mathrm{b}}$ Department of Agricultural and Food Sciences (DiSTAL), University of Bologna, Italy
}

\section{A R T I C L E I N F O}

\section{Keywords:}

Ricotta cheese whey

Scotta

Lactobionic acid

LBA

Pseudomonas sp.

Biorefinery

\begin{abstract}
A B S T R A C T
Lactobionic acid (LBA) is a fine chemical largely applied in the food, chemical, cosmetics and pharmaceutical industries. Here, its production from ricotta cheese whey (RCW), or scotta, the main by-product obtained from ricotta cheese production process and currently employed mainly for cattle feed, was evaluated. Among seven bacterial species tested, only two Pseudomonas taetrolens strains were selected after preliminary screening in shake-flasks. When autoclaved RCW was used, a lactobionic acid titer of $34.25 \pm 2.86 \mathrm{~g} / \mathrm{l}$, with a conversion yield (defined as mol LBA/mol of consumed lactose $\%$ ) of up to $85 \pm 7.0 \%$, was obtained after $48 \mathrm{~h}$ of batch fermentation in $3 \mathrm{~L}$ stirred tank bioreactor. This study is a preliminary investigation on the potential industrial use of scotta as a substrate for bacterial growth and lactobionic acid production that details the possible biotechnological valorization pathways and feasibility of the process.
\end{abstract}

\section{Introduction}

Lactobionic acid (LBA) is a complex polyhydroxy acid composed of a galactose molecule linked to a gluconic acid unit by an ether-like linkage. Thanks to its particular chemical structure with several hydroxyl groups, LBA has antioxidant, ion-chelating and humectant properties; it is biodegradable, biocompatible and non-cytotoxic [1-3]. LBA is widely used in the pharmaceutical industry as a ligand molecule in drug-delivery systems (hepatocytes targeted cells) [4,5], as a biofunctionalization agent in biocompatible scaffolds for injured tissue and organs repair [6,7] and as a coating material in nanoparticles for bioimaging and bio-detection applications [8,9]. It also has an important role in preservative solutions for organ storage to avoid oxidative damage, due to its chelating capacity for metal ions [10], and in cosmetic products due to its anti-aging and regenerative skin-care effects [3]. Moreover, addition of LBA has a key role in antibiotic formulations such as erythromycin by increasing their water solubility [11] as well as in anticoagulant and antithrombotic drugs [12]. In the chemical industry, LBA is used as an additive in biodegradable detergents and sugar-based surfactants [13] to improve their physico-chemical properties and reduce their environmental impact. The use of LBA in functional foods has been approved by the FDA in the USA, thanks to its prebiotic effects, low-calorie sweetener $(2 \mathrm{kcal} / \mathrm{g})$, gelling, stabilizing and aging inhibitor effects $[2,14,15]$. In addition, LBA may stimulate calcium absorption to aid in avoiding health disorders associated with this shortage of this mineral [16].

LBA was first synthetized by Fisher and Meyer through chemical oxidation of lactose with bromine [17]. It is currently prepared via electrochemical and heterogeneous catalytic oxidations involving refined-lactose oxidation, while harmful and costly catalysts with undesirable side-reaction products [18-20] have been shelved in favour of more interesting biocatalytic processes that lead to LBA through a lactobiono- $\delta$-lactone intermediate. They comprise enzymatic synthesis, an expensive process due to the need for redox mediators and cofactors [21].

Recently, there have been several attempts to produce LBA via biotechnological routes using inexpensive feedstock as a lactose source. To date, all available reports deal with the use of cheese whey as substrate [22]. Cheese whey is a raw material for the production of ricotta cheese, a typical dairy product in Mediterranean countries obtained by heat-coagulation $\left(85-90^{\circ} \mathrm{C}, 25 \mathrm{~min}\right)$ of proteins in whey [23]. The main byproduct of this process is ricotta cheese whey (RCW), or scotta, that still contains between $4 \%$ and $5 \%(w / w)$ of lactose [23]. In contrast to raw cheese whey characterized by high protein content, i.e. $0.6-1.0 \%$ [24], which makes it suitable for different applications including production of ricotta or the recovery of whey proteins, scotta is characterized by a low protein content, i.e. $0.15-0.22 \%$ [25], rendering it unsuitable for processes aimed at protein valorization. Moreover, due to the characteristics of the production process, including the combination of thermal and acidic treatment as well as the addition of salt, a higher

\footnotetext{
* Corresponding author at: Department of Civil, Chemical, Environmental and Materials Engineering (DICAM), University of Bologna-via Terracini 28, 40131 Bologna, Italy.

E-mail address: noura.raddadi@unibo.it (N. Raddadi).
} 
salt content is found in scotta (1.0-1.3\%) [25], compared to cheese whey that has only $0.11 \%$ [24]. Having a biochemical oxygen demand (BOD) of $50 \mathrm{~g} / 1$ and chemical oxygen demand (COD) of $80 \mathrm{~g} / 1$, scotta presents pollution problems and its disposal is an added cost for the dairy industry. In Italy, about 1 million tons of scotta are produced each year. Currently, it is employed mainly for cattle feed [25]. Attempts to valorize RCW have been performed through lactose bioconversion into lactic acid and ethanol $[25,26]$ but its use for the production of lactobionic acid has not yet been reported.

The aim of the present study was to develop and validate a laboratory scale biotechnological process for the production of LBA from scotta by pure bacterial cultures of the genera Pseudomonas sp. and Acetobacter sp. in order to demonstrate the feasibility of microbial LBA production from this highly available cheese whey byproduct characterized by low protein and relatively high salt contents. This was with the perspective of exploitation of the results for the development of an optimized pilot scale fermentation process. Furthermore, in regard to downstream processing, since the recovery techniques including electrodialysis and cation exchange resins have drawbacks such as low recovery efficiency and/or high cost $[27,28]$, another perspective would be the evaluation of the feasibility of alternative membrane separation techniques for the recovery of LBA in an industrial framework.

\section{Materials and methods}

\section{Microorganisms}

Seven bacterial strains were used. Pseudomonas taetrolens LMG 2336 was obtained from the Belgian Coordinated Collection of Microorganisms (Gent, Belgium) and the other six (Pseudomonas taetrolens DSM 21104; Pseudomonas fluorescens DSM 50106; Pseudomonas chlororaphis DSM 50083; Pseudomonas citronellolis DSM 50382; Acetobacter orientalis DSM 15550; Acetobacter syzygii DSM 15548) were from the DSMZ culture collection. The Pseudomonas sp. and Acetobacter sp. strains were grown in nutrient broth and acetic acid bacterium media, respectively. Strains were maintained frozen $\left(-80^{\circ} \mathrm{C}\right)$ in their corresponding growth media supplemented with $20 \% \mathrm{v} / \mathrm{v}$ glycerol.

\section{Inoculum preparation}

A loopful of each strain grown on agar plate was used to inoculate a $100 \mathrm{~mL}$ flask containing $20 \mathrm{~mL}$ of nutrient broth or acetic acid bacterium medium. The preculture flasks were incubated on an orbital shaker at $150 \mathrm{rpm}$ and $30^{\circ} \mathrm{C}$ for $12 \mathrm{~h}$ and $48 \mathrm{~h}$ for Pseudomonas and Acetobacter strains, respectively. Active cells from precultures were then employed as inoculum in shake flasks containing synthetic medium (composition in $\mathrm{g} / \mathrm{l}$ : 2 peptone, 1 yeast extract, $0.2 \mathrm{~K}_{2} \mathrm{HPO}_{4}$ and 10 or 50 chemically pure lactose purchased from Sigma, Italy) adjusted to the appropriate $\mathrm{pH}$ (7 for Pseudomonas species and 6.5 for Acetobacter) by addition of $2 \mathrm{M} \mathrm{NaOH}$ before autoclaving, or sterile RCW from bovine milk. The RCW obtained from three production batches was provided by a large Italian dairy and cheese factory and had the following average composition (g/100 g): lactose, 4.5-5; proteins, 0.26-0.58; ash, $0.88-1.29$ and fats $0.01-0.53$.

\section{Batch cultures in shake-flasks}

Bioconversion experiments were performed in $500 \mathrm{~mL}$ flasks containing $250 \mathrm{~mL}$ of synthetic medium supplemented with lactose at a final concentration of 10 or $50 \mathrm{~g} / \mathrm{l}$, or RCW sterilized by autoclaving. The flasks were inoculated with $5 \% \mathrm{v} / \mathrm{v}$ of precultures grown on nutrient broth or acetic acid bacterium medium. The cultures were incubated on an orbital shaker at $150 \mathrm{rpm}$ and $30^{\circ} \mathrm{C}$ for up to $144 \mathrm{~h}$. Samples were aseptically withdrawn after $0,3,6,24,48,72$ and $144 \mathrm{~h}$ of incubation for growth monitoring and quantification of produced LBA and residual lactose.

\section{Batch cultures in a stirred tank bioreactor}

LBA production by the most promising strains was performed in a $3 \mathrm{~L}$ bioreactor (BIOSTAT ${ }^{\circ}$ B Sartorius) with a working volume of $1.5 \mathrm{~L}$ at $30{ }^{\circ} \mathrm{C}, \mathrm{pH} 7$ and an aeration rate of $0.3 \mathrm{~L} / \mathrm{min}$. Agitation was automatically adjusted via an agitation cascade from 200 to $800 \mathrm{rpm}$ to keep dissolved oxygen tension above $20 \%$. Excessive foam formation was limited by automatic addition of 1:10-diluited Y-30 emulsion (SigmaAldrich). Samples were aseptically withdrawn after 0, 3, 6, 24, 30, 48, 72 and $80 \mathrm{~h}$ of incubation for growth monitoring and quantification of produced LBA and residual lactose.

\section{Analytical methods}

Bacterial growth was monitored by cell counts using the drop plate method [29] and growth curves were established by plotting the $\log _{10}$ $\mathrm{CFU} / \mathrm{ml}$ as a function of time. $\mathrm{pH}$ values were measured using a $\mathrm{pH}$ meter (Thermo Orion Model 720A, Research Inc., Beverly, MA, USA) and a $\mathrm{pH}$ probe (Orion 81-04).

Quantification of the lactobionic acid produced, the residual lactose as well as potential byproducts including lactic acid was performed by high performance liquid chromatography (HPLC). Samples were centrifuged $(14,000 \mathrm{rpm}$ for $10 \mathrm{~min})$ to remove cell debris and filtered through a cellulose acetate membrane $0.22 \mu \mathrm{m}-25 \mathrm{~mm}$ filter (GVS Filter Technology). HPLC analyses were carried out in a liquid chromatography system (Agilent 1260 Infinity) equipped with an Agilent Hi-Plex Ligand Exchange Columns $(\mathrm{H}+) 300 \times 7.8 \mathrm{~mm}$ set at $75^{\circ} \mathrm{C}$, coupled to a refractive index detector at $40^{\circ} \mathrm{C}$. The mobile phase consisted of a $0.1 \mathrm{mM} \mathrm{H}_{2} \mathrm{SO}_{4}$ (pH 3.4) solution at a flow rate of $0.5 \mathrm{~mL} / \mathrm{min}$. Samples were quantified according to HPLC-grade external analytical standards, lactose and lactobionic acid, obtained from Sigma-Aldrich (Milan, Italy). Data acquisition and analysis were performed with ChemStation software (Agilent). All results are presented as the average of data from three independent experiments.

\section{Results and discussion}

Preliminary screening of oxidative bioconversion by Pseudomonas sp. and Acetobacter sp.

In a first step, the ability of the seven selected bacterial strains to grow and convert lactose into LBA was evaluated on synthetic medium containing $10 \mathrm{~g} / \mathrm{l}$ of chemically pure lactose in shake flasks seeded with a $5 \% \mathrm{v} / \mathrm{v}$ of a preculture grown for $12 \mathrm{~h}$ on the corresponding medium. The microbial growth evaluated by drop plate method revealed that all the isolates were able to grow since an increase in counts of $>0.5 \log _{10}$ $\mathrm{CFU} / \mathrm{ml}$, the commonly accepted microbiological experimental error, was recorded (Fig. 1A). The $\mathrm{pH}$ of the broth increased remarkably on growth of $P$. fluorescens, $P$. chlororaphis and $P$. citronellolis, reaching values of up to 8.8; a slight increase was observed in the case of the two Acetobacter strains (from 6.5 to 7) (Fig. 1B). The appearance of nitrogen by-products from protein metabolism during bacterial growth may have been the reason for the increase in $\mathrm{pH}$. The increase of broth $\mathrm{pH}$ was also observed with $P$. taetrolens LMG 2336 by Alonso et al. [22] employing $0.64 \mathrm{~g} / \mathrm{l}$ of biomass (about $30 \% \mathrm{v} / \mathrm{v}$ ) as inoculum into proteinrich sweet cheese medium in shake flasks. However, under the experimental conditions applied herein, in the case of $P$. taetrolens strains we did not observe a significant rise of broth $\mathrm{pH}$, which remained almost constant during growth (around 7). On the contrary, remarkable broth acidification was observed after $24 \mathrm{~h}$ of incubation reaching the lowest values of $\mathrm{pH} 3.9$ and $\mathrm{pH} 4.2$ for the strain P. taetrolens LMG 2336 and $P$. taetrolens DSM 21104, respectively, after $144 \mathrm{~h}$ of incubation.

HPLC analyses performed on cell-free culture supernatants of the different strains confirmed the detection of $6.30 \pm 0.1$ (conversion yield $=77.36 \pm 2.98 \%$ ) $\quad$ and $\quad 7.67 \pm 0.20 \mathrm{~g} / \mathrm{l} \quad$ (conversion yield $=89.58 \pm 1.46 \%$ ) of LBA by strains LMG 2336 and DSM 21104, 
A

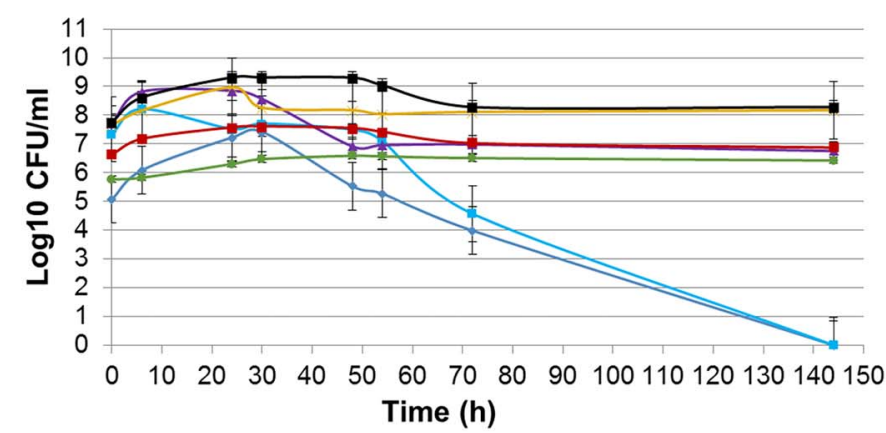

B

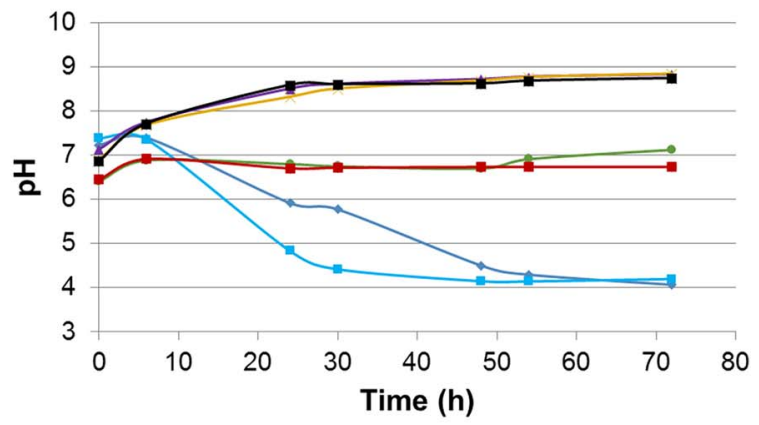

$\begin{array}{ll}\rightarrow \text { P. taetrolens LMG } 2336 & \rightarrow-P \text {. taetrolens DSM } 21104 \\ \rightarrow-P . \text { fluorescens } & \rightarrow \text {.chlororaphis } \\ \rightarrow-P \text {. citronellolis } & \rightarrow \text { A.orientalis }\end{array}$

$\begin{array}{ll}\rightarrow-P . \text { taetrolens LMG2336 } & \rightarrow-P \text {. taetrolens DSM21104 } \\ \rightarrow-P \text {. fluorescens } & \rightarrow P \text {. chlororaphis } \\ \rightarrow-P \text {. citronellolis } & \rightarrow-A \text {. orientalis } \\ \rightarrow-A . \text { syzygii } & \end{array}$

C

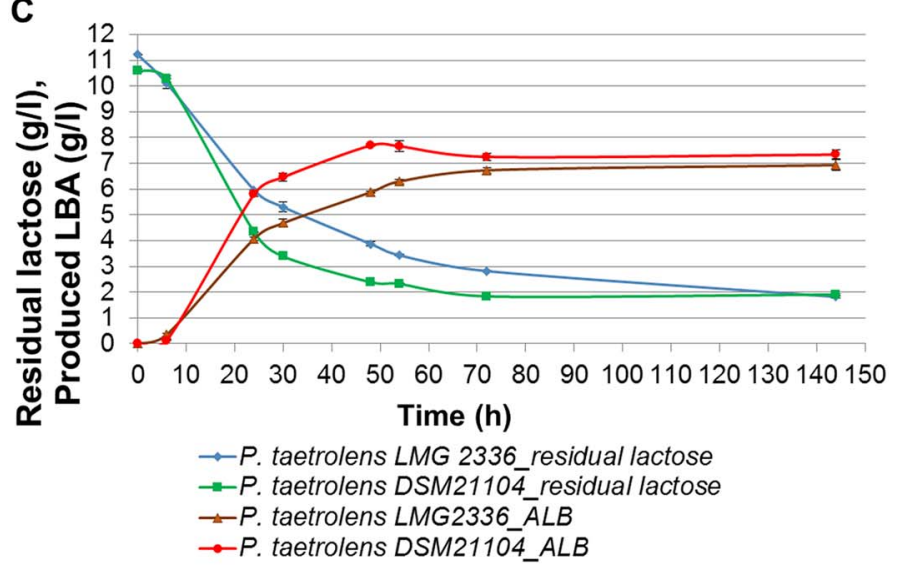

- A. sygyzii

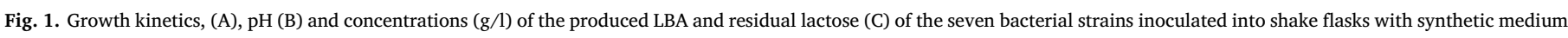
containing $10 \mathrm{~g} / \mathrm{l}$ of chemically pure lactose (Sigma) as substrate. Error bars show S.D. calculated from three independent experiments.

respectively, after $54 \mathrm{~h}$ and which remained almost constant for up to $144 \mathrm{~h}$ of incubation (Fig. 1C). Although the other Pseudomonas and Acetobacter species were able to grow, no significant lactose consumption or LBA production were detected under the experimental conditions applied. The results confirmed the ability of $P$. taetrolens strains to produce LBA from lactose and are in agreement with those previously reported for the same species where a conversion yield of $87 \%$ in shakeflask culture was observed after $48 \mathrm{~h} \mathrm{[22].}$

\section{Growth of P. taetrolens strains on scotta and LBA production in shake flasks}

Based on the results of the screening carried out on synthetic medium, only the two Pseudomonas taetrolens strains were considered for the experiments using scotta samples obtained from three different manufacturing batches and having a lactose content of about 45-50 g/l. Starting from a cell concentration of $\sim 10^{7} \mathrm{CFU} / \mathrm{ml}$, a maximum cell density of up to $10^{9} \mathrm{CFU} / \mathrm{ml}$ was achieved after $24 \mathrm{~h}-48 \mathrm{~h}$ incubation, followed by a progressive decrease in cell counts. The $\mathrm{pH}$ of the broth fell progressively from 6.44 to lowest values of 3.87 and 4.06 for $P$. taetrolens LMG 2336 and $P$. taetrolens DSM 21104, respectively, after $168 \mathrm{~h}$ of incubation (Fig. 2A, B). HPLC analyses allowed detection of low concentrations of LBA after $24 \mathrm{~h}$ of incubation which increased with increasing incubation time. The highest titres of $35.39 \pm 1.76 \mathrm{~g} / 1$ and $27.50 \pm 0.77 \mathrm{~g} / \mathrm{l}$, corresponding to bioconversion yields of $87.8 \pm 2.75 \%$ and $80.8 \pm 11.00 \%$ for $P$. taetrolens LMG 2336 and $P$. taetrolens DSM 21104, respectively, were achieved after $120 \mathrm{~h}$ incubation (Fig. 2). Further prolongation of the incubation time to $168 \mathrm{~h}$ did not result in significant improvement of productivity.

It is interesting to highlight that, using a comparable concentration of chemically pure lactose (D-lactose monohydrate, Sigma), lower titres of LBA were achieved with both $P$. taetrolens strains. Indeed, using an initial concentration of $55 \mathrm{~g} / 1$ of lactose, HPLC analyses detected $13.16 \pm 1.25 \mathrm{~g} / \mathrm{l}$ and $18.61 \pm 0.01$ of LBA for $P$. taetrolens LMG 2336 and $P$. taetrolens DSM 21104, respectively. A decrease in $\mathrm{pH}$ values from 7 to 3.44 and 3.2 was observed after $48 \mathrm{~h}$ of incubation in the case of $P$. taetrolens LMG 2336 and of $P$. taetrolens DSM 21104, respectively. Prolongation of the incubation time to $72 \mathrm{~h}$ did not result in significant improvement of the yield and a large quantity of lactose remained unused (data not shown). This effect may be due to acidification of the medium resulting in decreased cell viability and/or inhibition of the enzymes involved in LBA production from lactose. In contrast, the higher titres of LBA and lower acidification of the broth observed when scotta was used as the substrate could be due to the presence of compounds able to protect bacterial cells from the effects of low $\mathrm{pH}$, as suggested by the improvement (compared to the experiment with pure lactose) of cell viability and cultivability (expressed as $\mathrm{CFU} / \mathrm{mL}$ ), especially at low $\mathrm{pH}$ values. Indeed, using $55 \mathrm{~g} / 1$ of D-lactose as substrate, no $\mathrm{CFU} / \mathrm{ml}$ were detected by the drop method for either P.taetrolens strain after $48 \mathrm{~h}$ when the $\mathrm{pH}$ value was lower than 3.4, suggesting that the cells were damaged or transformed to uncultivable forms as previously observed [30]. However, with scotta the buffering effect due to the presence of macromolecules (such as proteins, peptides 


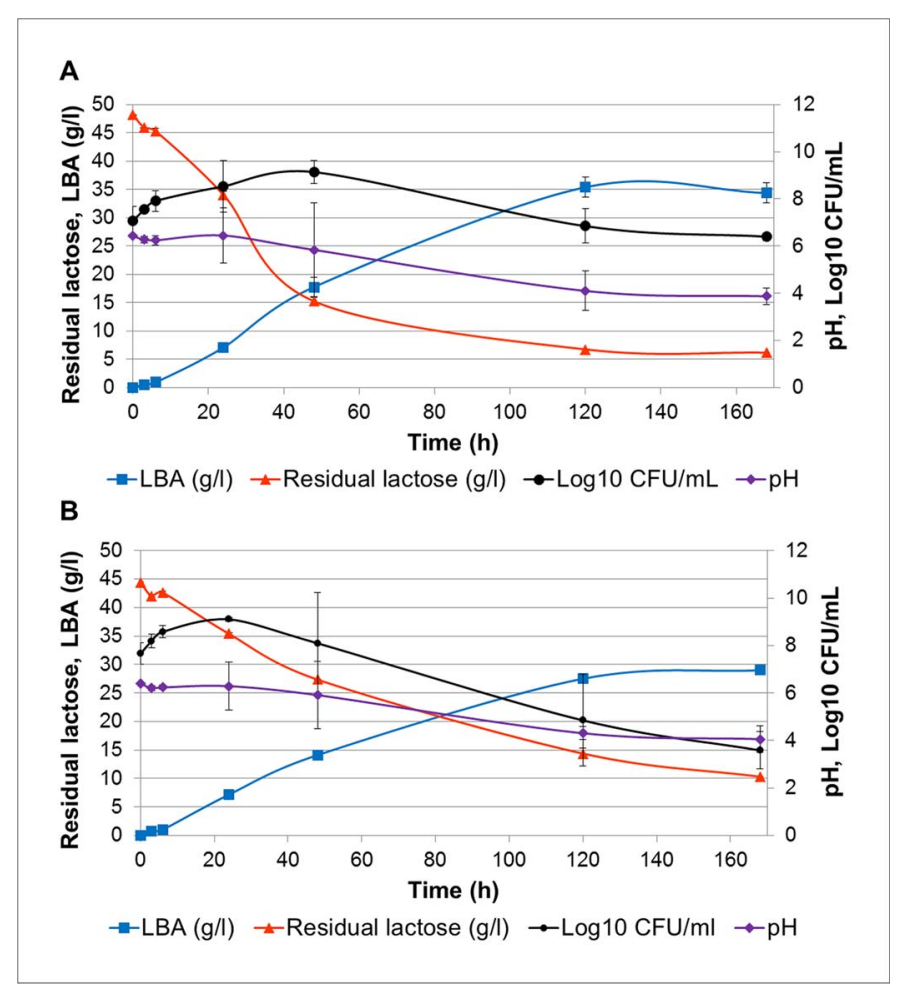

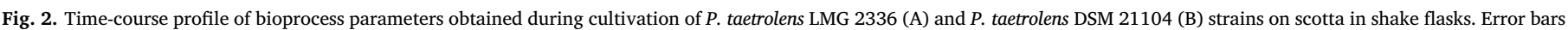
show S.D. calculated from three independent experiments.

and fat) led to a gradual decrease in $\mathrm{pH}$, restricting cellular stress conditions. Indeed, the bovine scotta used in this study has an average composition $(\mathrm{g} / 100 \mathrm{~g})$ of lactose $4.5-5$, protein $0.26-0.58$, ash $0.88-1.29$ and fats $0.01-0.53$. Also, the few literature reports available described similar bovine scotta characteristics and composition. Sansonetti et al. [25] reported on $0.15-0.22 \%, 4.8-5 \% ; 1.1-1.3 \%$, and $0.2-0.25 \%$ for protein, lactose, salts and organic acids contents, respectively. Pisponen et al. [31] reported the following scotta composition $\left(\%_{\mathrm{w} / \mathrm{w}}\right)$ : fat $0.26 \pm 0.10$; protein $0.50 \pm 0.02$; lactose $4.14 \pm 0.11$ and ash content $0.62 \pm 0.02$ [31]. Since this is the first study on the use of scotta for the production of LBA, comparison of the LBA productivity results with previous work is not possible. However, similar LBA titres (35-40 g/1) were obtained by Alonso et al. [22] after $48 \mathrm{~h}$ incubation in shake flasks employing cheese whey with P.taetrolens LMG 2336. Hence, the use of lactose from a natural matrix such as dairy industry waste improves the bioconversion capacity of Pseudomonas taetrolens to produce LBA via lactose oxidation reaction.

\section{LBA production by $P$. taetrolens from scotta in $3 L$ STR fermenter}

The bioreactors were inoculated with $5 \%(\mathrm{v} / \mathrm{v})$ of overnight precultures grown on nutrient broth medium. Starting from cell counts of $10^{8} \mathrm{CFU} / \mathrm{ml}$, a cell count higher than $10^{9} \mathrm{CFU} / \mathrm{ml}$ was achieved after $8 \mathrm{~h}$ incubation and the cell concentration remained almost constant throughout the incubation time. For both cultures, LBA production started after $6 \mathrm{~h}$ incubation. After $48 \mathrm{~h}$ of batch fermentation, $P$. taetrolens LMG 2336 produced $34.25 \pm 2.86 \mathrm{~g} / 1$ of LBA (with $85 \pm 7 \%$ of conversion yield); a LBA titre of $30.18 \pm 0.3 \mathrm{~g} / 1$ (with $84 \pm 7 \%$ of conversion yield) was achieved with $P$. taetrolens DSM 21104 (Fig. 3). For the strain LMG 2336, prolongation of the incubation up to $72 \mathrm{~h}$ did not result in significant improvement in productivity. However, after $72 \mathrm{~h}$ of batch fermentation, DSM 21104 was able to produce $36.32 \pm 2.96 \mathrm{~g} / \mathrm{l}$ of LBA (with $94.95 \pm 2.76 \%$ of conversion yield). The yields obtained using the $3 \mathrm{~L}$ bioreactor were comparable to $(P$. taetrolens LMG 2336) or higher than (P. taetrolens DSM 21104) those obtained in shake flask experiments, with an important reduction of the time required from 120 to $48 \mathrm{~h}$ for almost total lactose consumption, thanks to constant control of the parameters. The yields obtained in this preliminary study using scotta as substrate without nutrient supplementation were slightly lower than those reported [22]. In that study, a concentration of $42.4 \mathrm{~g} / 1$ of LBA and a bioconversion yield of $100 \%$ were obtained in a $2 \mathrm{~L}$ bioreactor after $32 \mathrm{~h}$ incubation of $P$. taetrolens LMG2336 using sweet cheese whey as substrate and an inoculum of $30 \% \mathrm{v} / \mathrm{v}$. The yields obtained here are lower than those reported in [32], where an LBA concentration of $125.4 \mathrm{~g} / \mathrm{l}$ was achieved. However, in that study the process was based on the use of enzymes and $252 \mathrm{~g} / \mathrm{l}$ of chemically pure lactose solution. Finally, higher LBA titres were achieved by Alonso et al. [2], obtaining $164 \mathrm{~g} / 1$ of LBA in an optimized fed-batch process where co-feeding of concentrated lactose and highly concentrated cheese whey solutions supplemented with yeast extract and peptone was adopted.

\section{Conclusion}

The objective of this study was to evaluate the suitability of scotta, the byproduct of ricotta cheese manufacturing currently used mainly for feed preparation, as raw material for bacterial growth and LBA production. Among seven species tested for their ability to oxidise lactose into LBA when grown on synthetic medium supplemented with chemically pure lactose, two $P$. taetrolens strains obtained from two culture collections were selected and their bioconversion abilities were further characterized. In 3L stirred tank bioreactor batch processes, fermentation and bioconversion yields of $34.25 \pm 2.86 \mathrm{~g} / \mathrm{l} \mathrm{LBA}$ and $85 \pm 7 \%$ were achieved after $48 \mathrm{~h}$. To the best of our knowledge, this study shows for the first time that bovine scotta, a substrate completely different from cheese whey, can be used as substrate for the growth and production of LBA with results comparable to those obtained using cheese whey [22]. Moreover, it is worthwhile to stress that scotta, with an estimated production of about 1 million tons per year in Italy alone, is a dairy waste with high COD and BOD values, disposal of which 


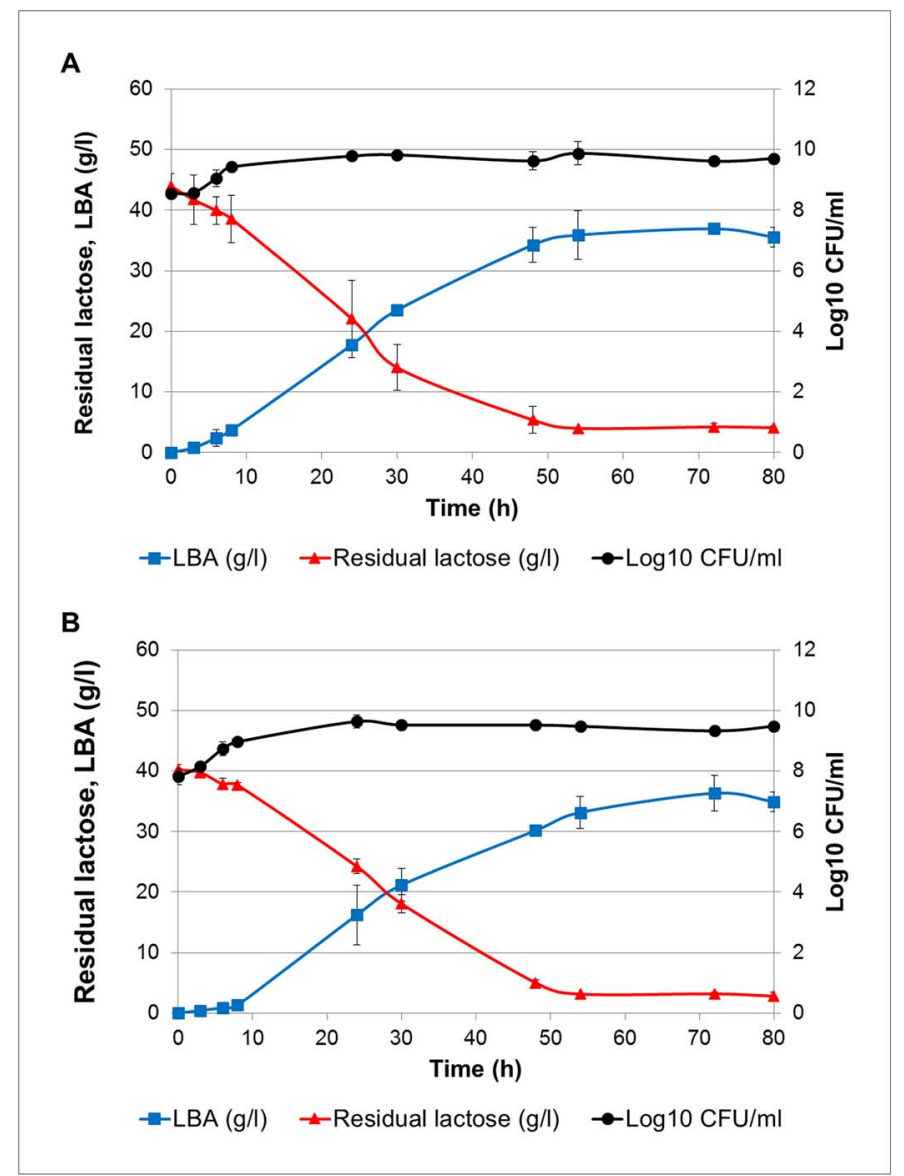

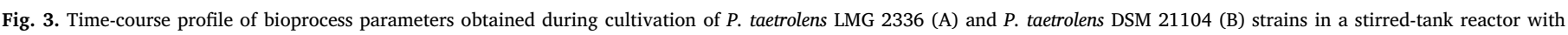
autoclaved ricotta cheese whey as substrate. Error bars show S.D. calculated from three independent experiments.

without treatment could create environmental problems. The proposed biotechnological process offers an interesting opportunity to jointly dispose and valorize scotta with the production of a highly valued fine chemical [33-37]. A more detailed investigation on the effects of feeding strategy, inoculum size and agitation on LBA productivity was beyond the objective of the present preliminary screening. Optimization of the bioconversion process through response surface methodology, a fed-batch process and the evaluation of the effect of cell immobilization on LBA yields is advisable. Moreover, set up of the downstream process for recovery of LBA remains necessary for industrial exploitation/implementation of this biorefinery process.

\section{Acknowledgments}

This work was supported by Italian Ministry for Education, University and Research (MIUR) in the framework of the project SO.FI.A (Cluster AGRIFOOD- CTN01_00230_450760). The authors also thank the laboratory technician Mara Mandrioli for her valuable support.

\section{References}

[1] Selim KMK, Xing ZC, Guo H, Kang IK. Immobilization of lactobionic acid on the surface of cadmium sulphide nanoparticles and their interaction with hepatocytes. $J$ Mater Sci Mater Med 2009;20:1945-53.

[2] Alonso S, Rendueles M, Díaz M. Bio-production of lactobionic acid: current status, applications and future prospects. Biotechnol Adv 2013;31(8):1275-91.

[3] Tasic-Kostov M, Pavlovic D, Lukic M, Jaksic I, Arsic I, Savic S. Lactobionic acid as antioxidant and moisturizing active in alkyl polyglucoside-based topical emulsions: the colloidal structure, stability and efficacy evaluation. Int J Cosmet Sci 2012;34:424-34.

[4] Kim EM, Jeong HJ, Kim SM, Sohn MH, Nah JW, et al. Asialoglycoprotein-receptor- targeted hepatocyte imaging using 99mTc galactosylated chitosan. Nucl Med Biol 2006;33:529-34.

[5] Lin WL, Chen TD, Liu CW. Synthesis and characterization of lactobionic acid grafted pegylated chitosan and nanoparticle complex application. Polymer 2009;50:4166-74.

[6] Chung TW, Yang J, Akaike T, Cho KY, Nah JW, et al. Preparation of alginate/galactosylated chitosan scaffold for hepatocyte attachment. Biomaterials $2002 ; 23: 2827-34$.

[7] Fan J, Shang Y, Yang J. Preparation and characterization of chitosan/galactosylated hyaluronic acid scaffolds for primary hepatocytes culture. J Mater Sci Mater Med 2010;21:319-27.

[8] Kekkonen V, Lafreniere N, Ebara M, Saito A, Sawa Y, Narain R. Synthesis and characterization of biocompatible magnetic glyconanoparticles. J Magn Mater 2009;321:1393-6.

[9] Selim KMK, Ha YS, Kim SJ, Chang Y, Kim TJ, et al. Surface modification of magnetite nanoparticles using lactobionic acid and their interaction with hepatocytes. Biomaterials 2007;28:710-6.

[10] Hart NA, Leuvenink HGD, Ploeg RJ. New solutions in organ preservation. Transplant Rev 2002;16(3):131-41.

[11] Nakano H, Kiryu T, Kiso T, Murakami H. Biocatalityc production of Lactobionic acid. In: Hou CT, Shaw JF, editors. Biocatalysis and biomolecular engineering. New Jersey: John Wiley \& Sons Inc; 2010. p. 391-404.

[12] Gutiérrez LF, Hamoudi S, Belkacemi K. Lactobionic acid: a high-value-added lactose derivative for food and pharmaceutical applications. Int Dairy J 2012;26:103-11.

[13] Oskarsson H, Frankenberg M, Annerling A, Holmberg K. Adsorption of novel alkylaminoamide sugar surfactants at Tailor-made surfaces. J Surfactants Deterg 2007;10:41-52.

[14] Schaafsma G. Lactose and lactose derivatives as bioactive ingredients in human nutrition. Int Dairy J 2008;18:458-65.

[15] Oe K, Kimura T Aging inhibitor for bread. Japan Patent Application 2011 Pub. No.: JP2011177121.

[16] Nielsen PM, Hoeier E. Food products containing aldobionic acid. International Patent Application 2009 Pub. No.: WO 2009/007398 A1.

[17] Fisher E, Meyer J. Oxydation des milchzuckers. Ber Dtsch Chem Ges 1889;22:361-4

[18] Yang BY, Montgomery R. Oxidation of lactose with bromine. Carbohydr Res 2005;340:2698-705.

[19] Kuusisto J, Tokarev AV, Murzina EV, Roslund MU, Mikkola JP, et al. From renewable raw materials to high value-added fine chemicals-catalytic hydrogenation 
and oxidation of D-lactose. Catal Today 2007;121:92-9.

[20] Tokarev AV, Murzina EV, Eränen K, Markus H, Plomp AJ, et al, Lactose oxidation over palladium catalysts supported on active carbons and on carbon nanofibres. Res Chem Intermed 2009;35:155-74.

[21] Van Hecke W, Bhagwat A, Ludwing R, Dewulf J, Haltrich D, Van Langenhove H. Kinetic modeling of a bi-enzymatic system for efficient conversion of lactose to lactobionic acid. Biotechnol Bioeng 2009;102:1475-82.

[22] Alonso S, Rendueles M, Díaz M. Efficient lactobionic acid production from whey by Pseudomonas taetrolens under pH-shift conditions. Bioresour Technol 2011;102:9730-6.

[23] Salvatore E, Pes M, Falchi G, Pagnozzi D, Furesi S, et al. Effect of whey concentration on protein recovery in fresh ovine ricotta cheese. J Dairy Sci 2014;97(8):4686-94.

[24] Yadav JS, Yan S, Pilli S, Kumar L, Tyagi RD, Surampalli RY. Cheese whey: a potential resource to transform into bioprotein, functional/nutritional proteins and bioactive peptides. Biotechnol Adv 2015;33:756-74.

[25] Sansonetti S, Curcio S, Calabrò V, Iorio G. Optimization of ricotta cheese whey (RCW) fermentation by response surface methodology. Bioresour Technol 2010;101:9156-62.

[26] Secchi N, Giunta D, Pretti L, García MR, Roggio T, et al. Bioconversion of ovine scotta into lactic acid with pure and mixed cultures of lactid acid bacteria. J Ind Microbiol Biotechnol 2012;39:175-81.

[27] Pedruzzi Borges I, da Silva EA, Rodrigues AE. Selection of resins, equilibrium an dsorption kinetics of lactobionic acid, fructose, lactose and sorbitol. Sep Purif Technol 2008;63:600-11.

[28] Peretti FA, Silveira MM, Zeni M. Use of electrodialysis technique for the separation of lactobionic acid produced by Zymomonas mobilis. Desalination 2009;246:253-7.

[29] Herigstad B, Hamilton M, Heersink J. How to optimize the drop plate method for enumerating bacteria. J Microbiol Methods 2001;44:121-9.

[30] Alonso S, Rendueles M, Díaz M. Physiological heterogeneity of Pseudomonas taetrolens during Lactobionic acid production. Appl Microbiol Biotechnol 2012;96:1465-77.

[31] Pisponen A, Pajumägi S, Mootse H, Karus A, Poikalainen V. The lactose from Ricotta cheese whey: the effect of $\mathrm{pH}$ and concentration on size and morphology of lactose crystals. Dairy Sci Technol 2013;93:477-86.

[32] Pedruzzi I, da Silva EAB, Rodrigues AE. Production of lactobionic acid from lactose/ fructose substrate using GFOR/GL enzymes from Zymomonas mobilis cells: a kinetic study. Enzyme Microb Technol 2011;49:183-91.

[33] Chen H, Zhong Q. Lactobionic acid enhances the synergistic effect of nisin and thymol against Listeria monocytogenes Scott A in tryptic soy broth and milk. Int J Food Microbiol 2017;260:36-41.

[34] García C, Rendueles M, Díaz M. Synbiotic fermentation for the co-production of lactic and lactobionic acids from residual dairy whey. Biotechnol Prog 2017. http:// dx.doi.org/10.1002/btpr.2507.

[35] Chaouat C, Balayssac S, Malet-Martino M, Belaubre F, Questel E, et al. Green microparticles based on a chitosan/lactobionic acid/linoleic acid association: characterisation and evaluation as a new carrier system for cosmetics. J Microencapsul 2017;34:162-70.

[36] Tsend-Ayush A, Zhu X, Ding Y, Yao J, Yin L, et al. Lactobionic acid-conjugated TPGS nanoparticles for enhancing therapeutic efficacy of etoposide against hepatocellular carcinoma. Nanotechnology 2017;28:195602.

[37] Misugi CT, Savi LK, Iwankiw PK, Masson ML, de Oliveira MAS, et al. Effects of freezing and the cryoprotectant lactobionic acid in the structure of GlnK protein evaluated by circular dichroism (CD) and isothermal titration calorimetry (ITC). J Food Sci Technol 2017;54:236-43. 